Hydrology and Earth System Sciences, 8(3), 567-577 (2004) C EGU

\title{
Processing of pine (Pinus sylvestris) and birch (Betula pubescens) leaf material in a small river system in the northern Cairngorms, Scotland
}

\author{
P. Collen, E.J. Keay and B.R.S. Morrison \\ FRS - Freshwater Laboratory, Pitlochry, Perthshire, Scotland, PH16 5LB \\ Email for corresponding author: p.collen@marlab.ac.uk
}

\begin{abstract}
Processing rates, and macroinvertebrate colonisation, of pine needles and birch leaves were studied at eight sites on the river Nethy, a small river system in the Cairngorm region of north-eastern Scotland. Throughout this river system, processing rates were slow for pine ( $k$ values 0.0015-0.0034 day $\left.{ }^{-1}\right)$ and medium to fast for birch $\left(k\right.$ values 0.0085-0.0331 day $\left.{ }^{-1}\right)$. Plecopteran shredders dominated both pine and birch leaf packs during the early part of the experiment while chironomids were more important in the latter stages. It is suggested that the slow processing rate of pine needles could adversely affect the productivity of streams, particularly where needles provide the major allochthonous energy source and retentive features are limited. Forest managers should consider this when creating new pinewoods in treeless areas as it will take many years for the trees to reach a size at which they can effectively contribute retentive features, in the form of woody debris, to streams.
\end{abstract}

Keywords: leaf processing, pine needles, shredders, Pinus sylvestris, Betula pubescens, Scotland.

\section{Introduction}

Leaf material from riparian trees can provide a substantial proportion of the energy resources of streams (Fisher and Likens, 1972; Kaushik and Hynes, 1971; Petersen and Cummins, 1974). This allochthonous material is colonised by aquatic fungi and bacteria and subsequently by stream macroinvertebrates, particularly those from the functional feeding group described as shredders (Bärlocher, 1985; Cummins et al., 1989; Webster and Benfield, 1986). The rate at which these stream biota process the leaves is influenced by many factors such as stream chemistry and water temperature (Kaushik and Hynes, 1971). However, the physical and chemical characteristics of the leaf material dictate the relative rate at which leaves from different species of tree are processed (Irons et al., 1988; Webster and Benfield, 1986). For example, oak leaves have tough cuticles and high concentrations of lignin and tannin and are processed slowly while nitrogen rich alder leaves are processed rapidly (Gessner and Chauvet, 1994).
Generally, coniferous needles provide a poorer food resource for leaf processing biota than deciduous leaves and, consequently, have slower processing rates (Escudero et al., 1991; Friberg and Jacobsen, 1994; Rosset et al., 1982; Sedell et al., 1975). Various chemical and physical properties of needles have been associated with this slow rate of decomposition. Triska et al., (1975) found that leaves of deciduous species, such as red alder (Alnus rubra), which decomposed most rapidly were characterised by a very low concentration of lignin, while the more slowly decomposing needles of coniferous species, like Douglas-fir (Pseudotsuga menziesii), were characterised by higher lignin content. High levels of lignin have a strong negative influence on decomposition rates (Berg et al., 1982). Needles of red pine (Pinus resinosa) were colonised by fungi, particularly aquatic hyphomycetes, and the rate of colonisation was increased if the needles were halved longitudinally (Bärlocher et al., 1978); the needle cuticle could be an unsuitable substrate for hyphomycetes or that an intact 
cuticle may lock in inhibitory substances such as volatile oils.

In regions with mixed species riparian woodlands, the species-specific differences in processing rates, coupled with the variation in the timing of leaf fall among different tree species, provide a continuum of food resources for leaf processing biota (Cummins et al., 1989; Irons et al., 1988). Deciduous trees, especially riparian specialists such as some species of alder and willow, are common components of riparian woodlands. However, coniferous trees dominate these woodlands in some regions and, consequently, coniferous needles can provide a major proportion of the allochthonous material.

Compared with studies on the processing of deciduous leaves, there have been relatively few on coniferous needles. In the UK, discussion on the effects of conifers on stream productivity has focused mainly on coniferous plantations of exotic species, particularly sitka spruce (Picea sitchensis) (Dobson et al., 1995; Dobson and Cariss, 1999; Ormerod et al., 1993; Weatherly and Ormerod, 1990). Little attention has been paid to the effect of the native Scots pine (Pinus sylvestris) on streams.

Caledonian pinewood (semi-natural Scots pinewoods of the Scottish Highlands) features as an 'Annex 1' habitat within the EU Habitats Directive which requires Member States to prevent deterioration of these pinewoods and to maintain or restore them to favourable conservation status. The UK Government's Biodiversity Action Plan has identified the need to encourage the extension and creation of new native woodlands and the expansion of Scots pinewoods is highlighted in the Scottish Forestry Strategy (Anon, 2000). Such pinewoods will have the ability to influence streams through altering catchment processes (e.g. enhanced interception of air borne pollutants) and changing the characteristics of the stream (e.g. allochthonous inputs). Consequently, it is important to understand how Scots pinewoods influence stream ecosystems. This study compared the processing rates and the invertebrate colonisation of pine needles and birch leaves, in a small river system in Scotland.

\section{Methods}

The study was conducted in the River Nethy, a tributary of the River Spey, which flows from the northern region of the Cairngorm mountain range in north-east Scotland (Fig. 1). The Nethy catchment forms a large part of the Abernethy Forest Reserve. Detailed management plans for the reserve, including reducing deer numbers and terminating sheep grazing, are designed to encourage natural regeneration and expansion of the forested area (Beaumont et al., 1995). The upper reaches of the reserve are composed of intrusive granitic rocks which form the northern edge of the Cairngorm massif. The rest of the Nethy catchment is made up of a complex of undifferentiated schists. The soils generally reflect this geological pattern with alpine soils dominating the upper catchment. Most of the Nethy tributaries drain from the east where soils are mainly peaty podzols, peaty gleys and blanket peat.

Eight sites were selected on the River Nethy: four on the mainstem (MS1-MS4) and four on its major tributaries (TR1-TR4). Trees are absent from the two headwater sites (MS1 and TR1), isolated mature pines with limited regeneration feature at sites MS2, TR2 and TR3 while the remaining sites, MS3, MS4 and TR4, are within areas of well established pine forest. Deciduous trees are sparsely distributed in the study area with the exception of the riparian zone around MS4 where alder trees (Alnus glutinosa) in particular are plentiful. The streams in the study sections are predominantly riffle with pools comprising less than $20 \%$ of the surface area. Stream substrate consists mainly of cobbles but boulders are an important feature of the three lower mainstem sites. A summary of the physical characteristics of the study sites is given in Table 1 and further details of the study area are provided by Harriman et al. (1998).

Composite water samples were collected every week from all the sampling sites except TR 3 where dip samples were taken. The chemical analysis methods are described by Harriman et al. (1998). Water temperature was logged hourly at all sites.

Benthic macroinvertebrate samples were collected in May using a Hess sampler (Hess, 1941). Five Hess samples were taken from each site and the animals collected were counted and identified in the laboratory.

Leaf material was collected from mature trees in the lower Nethy catchment area by laying mesh nets below the trees during periods of active leaf fall. These leaves were airdried on paper tissue for three weeks. During November 1995, 25 mesh bags containing Scots pine needles and 25 bags containing downy birch (Betula pubescens) leaves were placed in riffle sections at every site. An additional five bags of each species were also placed in TR3 and TR4. The bags, measuring $20 \mathrm{~cm}$ by $10 \mathrm{~cm}$, were constructed with $4 \mathrm{~mm}$ Netlon mesh which, according to a similar study, would allow access for the majority of macroinvertebrates likely to be encountered at these sites (Collen, 1994). Each bag was individually labelled and held $1.5 \mathrm{~g} \pm 0.05 \mathrm{~g}$ dry weight of leaf material. At each site the bags were attached to five separate lengths of chain which were anchored into the stream substrate. Each length of chain held five bags of pine needles and five bags of birch leaves. To prevent the needles 


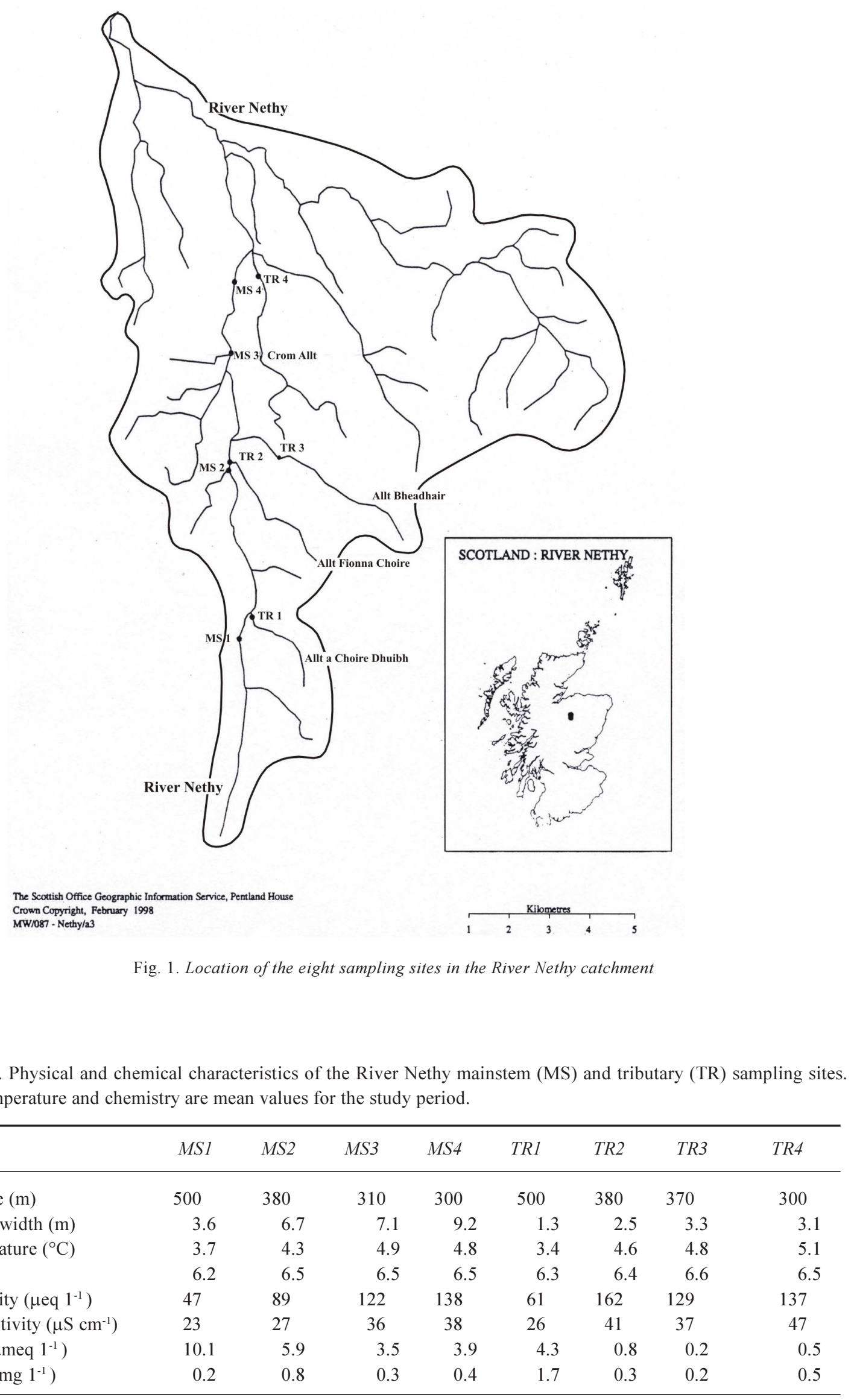

Table 1. Physical and chemical characteristics of the River Nethy mainstem (MS) and tributary (TR) sampling sites. The temperature and chemistry are mean values for the study period.

\begin{tabular}{lcccccccc}
\hline & $M S 1$ & MS2 & MS3 & MS4 & TR1 & TR2 & TR3 & TR4 \\
\hline Altitude $(\mathrm{m})$ & 500 & 380 & 310 & 300 & 500 & 380 & 370 & 300 \\
Stream width $(\mathrm{m})$ & 3.6 & 6.7 & 7.1 & 9.2 & 1.3 & 2.5 & 3.3 & 3.1 \\
Temperature $\left({ }^{\circ} \mathrm{C}\right)$ & 3.7 & 4.3 & 4.9 & 4.8 & 3.4 & 4.6 & 4.8 & 5.1 \\
pH & 6.2 & 6.5 & 6.5 & 6.5 & 6.3 & 6.4 & 6.6 & 6.5 \\
Alkalinity $\left(\mu \mathrm{eq} \mathrm{1} 1^{-1}\right)$ & 47 & 89 & 122 & 138 & 61 & 162 & 129 & 137 \\
Conductivity $\left(\mu \mathrm{S} \mathrm{cm} \mathrm{cm}^{-1}\right)$ & 23 & 27 & 36 & 38 & 26 & 41 & 37 & 47 \\
$\mathrm{NO}_{3}^{-}\left(\mu\right.$ meq 1 $\left.^{-1}\right)$ & 10.1 & 5.9 & 3.5 & 3.9 & 4.3 & 0.8 & 0.2 & 0.5 \\
$\mathrm{PO}_{4}^{-}\left(\mu \mathrm{mg} 1^{-1}\right)$ & 0.2 & 0.8 & 0.3 & 0.4 & 1.7 & 0.3 & 0.2 & 0.5 \\
\hline
\end{tabular}


from being washed out of the bags they were grouped into two bundles using rubber-castrating rings. The rings were placed just above the basal sheath of the needles and each bundle contained approximately 30 needles. Two rubber rings were also placed in the birch leaf bags.

The leaf bags were sampled after 12, 46, 88, 129 and 227 days exposure. Leaf bags were also sampled after 507 days exposure at TR3 and TR4. On each sampling visit, one pine and one birch leaf bag were removed from each chain. The individual leaf bags were then placed into polythene bags and transported to the laboratory in a cool box for analysis. Disturbance of the chains and neighbouring bags was kept to a minimum during sampling. The invertebrates from each bag were counted, weighed and identified. They were also assigned to functional feeding groups according to Merritt and Cummins (1984). The remaining leaf material was ashed at $500^{\circ} \mathrm{C}$ for 48 hours to obtain the ash free dry weight (AFDW).

Weight loss was expressed as a percentage of initial AFDW remaining. A negative exponential model (Petersen and Cummins, 1974) was fitted by linear regression to the natural logarithms of data to calculate decay coefficients $(k)$. Analysis of co-variance (ANCOVA), with time as the co-variate, was used to compare slopes among trees species in the same stream and among streams for each tree species. Significant differences in decay rates were determined using the Tukey test (Zar, 1984).

The Kruskal-Wallis test was used in the analysis of the numbers of animals in the leaf packs at the eight sites. This was followed by a multi-comparison test, a variation of the Tukey test (Zar, 1984), when differences in the data sets were found to be significant. The Mann-Whitney U-test was used to assess differences in the biomass of macroinvertebrates in the leaf packs at the eight sites. Significance testing in all analyses was based on a probability of $\mathrm{p}=0.05$.

\section{Results}

Mean chemistry for the study period is given in Table 1 . The sensitivity of the River Nethy, based on its alkalinity, declines from the upper (MS1) to lower site (MS4), with mean alkalinity values of $47 \mu \mathrm{eq} \mathrm{l}^{-1}$ and $138 \mu \mathrm{eq} \mathrm{l}^{-1}$ respectively. The alkalinity of TR1 is similar to MS1 but the other three tributaries, TR2, 3 and 4, provide high alkaline inputs to the main stem.

The mean $\mathrm{pH}$ values during the study period are remarkably similar in all eight sites ranging from 6.2 to 6.6. In a Scottish context, nitrate levels are low to intermediate $\left(0.2-10.1 \mu \mathrm{eq}^{-1}\right)$ and phosphate levels are generally low $\left(0.2-1.7 \mu \mathrm{g} \mathrm{l}^{-1}\right)$.
Table 2. Decay coefficients $(k)$ of leaf processing for pine and birch at 8 sites on the river Nethy. Summary of multiple comparisons (Tukey test) after analysis of co-variance is also shown and $k$ values followed by the same superscript letters, for pine and for birch, are not significantly different.

\begin{tabular}{lllll}
\hline Site & \multicolumn{2}{c}{ Pine needles } & \multicolumn{2}{c}{ Birch leaves } \\
& $k$ & $\mathrm{r}^{2}$ & $k$ & $\mathrm{r}^{2}$ \\
\hline MS1 & $0.0023^{\mathrm{ab}}$ & 0.92 & $0.0331^{\mathrm{a}}$ & 0.73 \\
MS2 & $0.0022^{\mathrm{abc}}$ & 0.90 & $0.0237^{\mathrm{ab}}$ & 0.78 \\
MS3 & $0.0019^{\mathrm{c}}$ & 0.93 & $0.0191^{\mathrm{b}}$ & 0.75 \\
MS4 & $0.0034^{\mathrm{ab}}$ & 0.80 & $0.0246^{\mathrm{ab}}$ & 0.88 \\
TR1 & $0.0025^{\mathrm{a}}$ & 0.90 & $0.0319^{\mathrm{a}}$ & 0.79 \\
TR2 & $0.0020^{\mathrm{bc}}$ & 0.91 & $0.0222^{\mathrm{b}}$ & 0.82 \\
TR3 & 0.0015 & 0.96 & $0.0085^{\mathrm{a}}$ & 0.90 \\
TR4 & $0.0023^{\mathrm{ab}}$ & 0.86 & $0.0151^{\mathrm{b}}$ & 0.61 \\
\hline
\end{tabular}

Clear differences were found between the rate of weight loss of birch leaves and pine needles at all the sites (Fig. 2). After 227 days processing, the percentage weight of birch leaf material remaining varied from $0-17 \%$ at the eight sites. The corresponding range for pine needles was 46-67\%. Only small differences were found in the pattern of weight loss of pine needles, amongst all the sites, throughout the 227 days. However, this was not the case with birch leaves where for example, less than $5 \%$ of the birch leaf material remained at MS1 and TR1 after 88 days, while it took MS2 129 days, and MS3, MS4 and TR2 227 days to reach this level. The rate of weight loss of birch leaves was slowest at TR3 and TR4 (Table 2).

No birch leaves remained in the leaf packs that had been held in TR3 and TR4 for 507 days. However, significant amounts of the pine needles were still in the packs at this time, with $49.7 \pm 5.3 \%$ and $33.3 \pm 7.9 \%$ of needles remaining in TR3 and TR4 respectively.

Generally, at each site, the percentage composition of the different macroinvertebrate functional feeding groups was similar in both the birch and pine leaf packs. Shredders and chironomids always made up at least $70 \%$ of the invertebrates in the leaf packs (Fig. 3). Shredders, in particular the stoneflies Amphinemura sulcicollis, Protonemura spp. and Leuctra spp., dominated the packs in the early part of the experimental period while chironomids generally became more important in the later stages of the study (Fig. 3). The range of macroinvertebrates found in the Hess samples (Table 3) was greater than those associated with the leaf packs although some species were only found in the leaf packs. Generally, during the early part of the experiment, there were significantly more macroinvertebrates in the birch packs than in the pine packs 
MS1

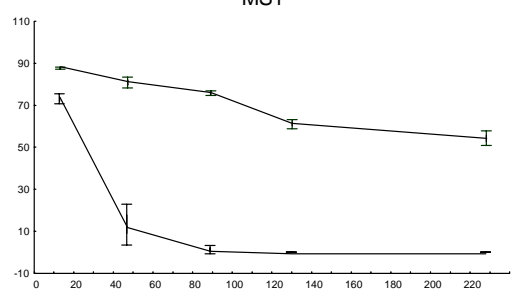

MS2
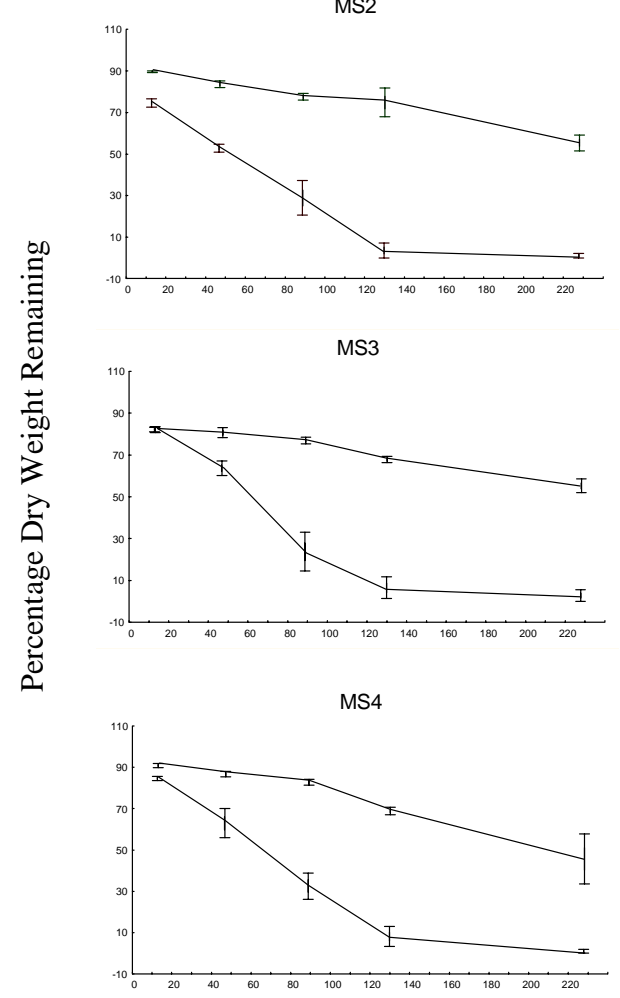

TR1

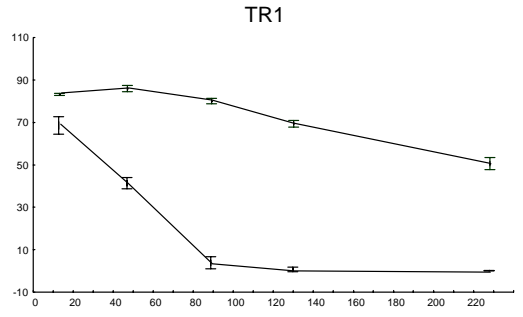

TR2

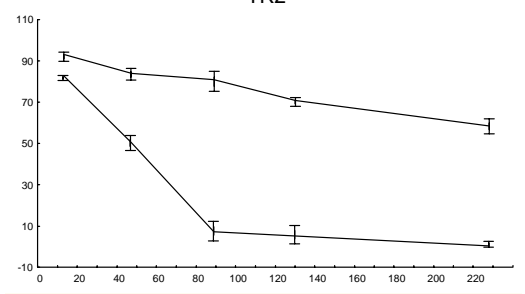

TR3

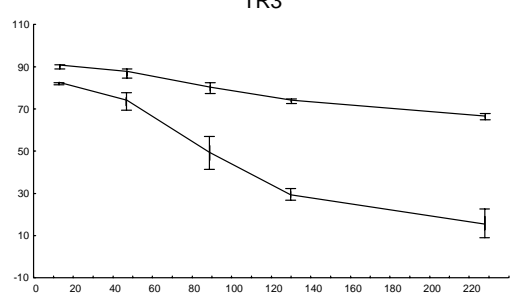

TR4

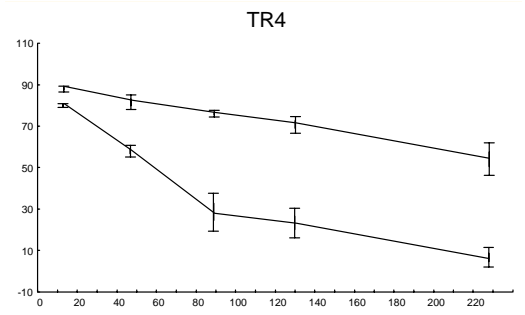

Days Processing

Upper graph $=$ pine $\quad$ Lower graph $=$ birch

Fig. 2. Percentage weight remaining of pine needles and birch leaves, at eight sites in the Nethy catchment, from Decmber 1995 to July 1996

(Fig. 4). This was not always the case in the later part of the experiment.

Differences in macroinvertebrate biomass on birch and pine leaf packs became less significant with time. After 12 days exposure, macroinvertebrate biomass was significantly greater in the birch packs at six of the eight sites, while the values for 46 days and 88 days were five and two sites respectively. There were no significant differences in macroinvertebrate biomass between birch and pine at any of the sites after 129 and 227 days exposure. However, as the exposure period increased, the amount of birch material remaining was significantly less than the amount of pine needles so, at all stages of the experiment, the quantity of macroinvertebrates per weight of remaining leaf material was greater in the birch packs.

\section{Discussion}

Substantial differences were found between the weight loss of birch leaves and pine needles throughout the Nethy catchment. According to the classification system described by Petersen and Cummins (1974), the decay coefficients recorded in this study place pine in the slow processing category and birch in the fast processing category (with the exception of birch in TR3 which would be placed in the medium category). The rate of weight loss for pine is similar to values reported for needles from Scots pine (Escudero et al., 1991), Douglas-fir (Pseudotsuga meziesii) and western hemlock (Tsuga heterophylla) (Sedell et al., 1975). However, the $k$ values for birch are generally higher than the range reported in other studies for this genus (Cowan et 

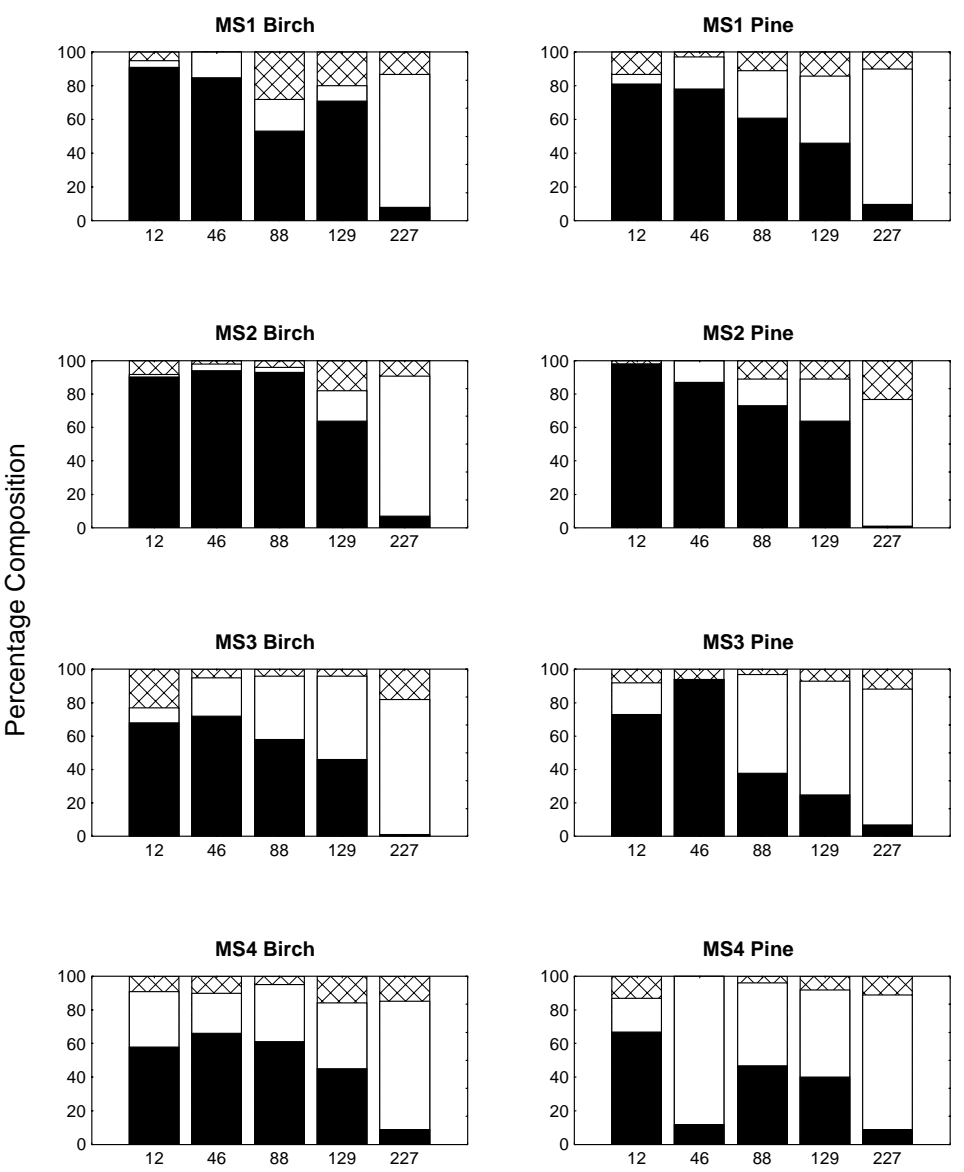

Days Processing

shredders $\square$ chironomids $\square$ others

Fig. 3a. Percentage composition of shredders, chironomids and other macroinvertebrate groups found in the experimental leaf packs at the four mainstem sites in the Nethy catchment

al., 1983; Meyer and Johnson, 1983). This could be related to the overall scarcity of deciduous leaf material in most of the Nethy sites. It has been suggested that leaf packs in small streams with low standing stocks of leaf detritus could attract high densities of shredders to that scarce resource resulting in fast processing rates (Cowan et al., 1983; Benfield and Webster, 1985).

There was little difference in the rate of weight loss of pine needles, in the first 88 days, among any of the sites. In contrast, there were differences in the rate of weight loss of birch leaves during this period with weight losses generally being faster in the upper parts of the catchment. It is likely, based on the number of shredders found in the leaf packs, that the birch leaves at these upper treeless sites were providing the shredders with a highly desirable food source.

In the Appalachian Mountains, pine needles (Pinus strobus) were processed faster in streams draining pine forests than in streams draining hardwood forests and this was related to the pine streams having a higher proportion of trichopteran shredders than the hardwood streams (Whiles and Wallace, 1997). This was not observed in the Nethy as the processing rate and macroinvertebrate associations in needle packs in TR4 (totally surrounded by pine trees) did not differ from the other sites. Sedell et al., (1975) found that the weight loss of needles was faster in larger streams, particularly after 100 days processing, when macroinvertebrates played the major role in the disappearance of the needle pack. This did not occur in the Nethy catchment where the weight loss more closely resembled the values found in the smaller streams described by Sedell et al. (1975).

The slowest processing rates, during the 227 days exposure period, for both needles and leaves were recorded at TR3 and this could not be related to water temperature or macroinvertebrate associations. However, this site had the lowest values for phosphate and nitrate and these nutrients are important factors influencing the processing rate of leaf material (Robinson and Gessner, 2000). The Nethy sites with 

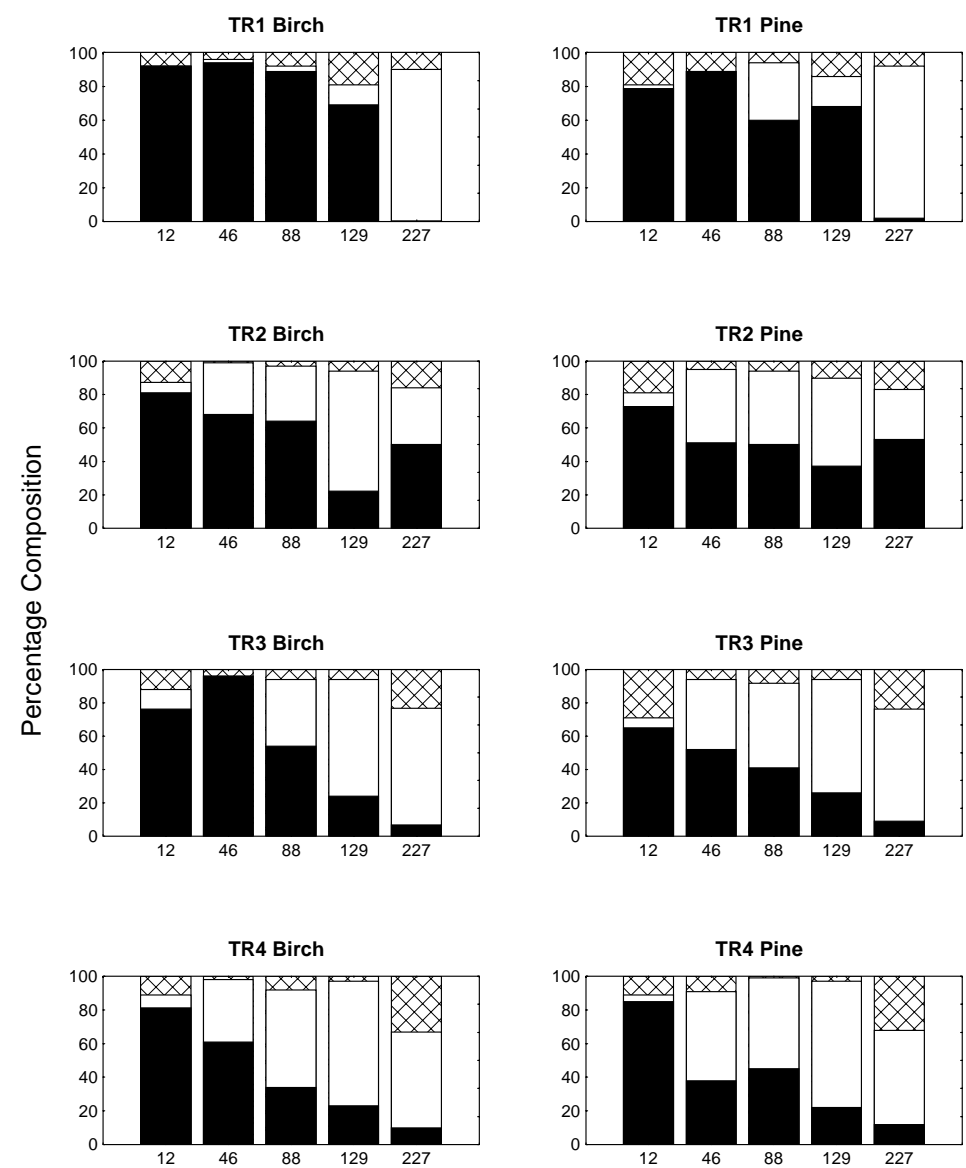

Days Processing

shredders $\square$ chironomids $\square$ others

Fig. 3b. Percentage composition of shredders, chironomids and other macroinvertebrate groups found in the experimental leaf packs at the four tributary sites in the Nethy catchment.

the fastest processing rates had the highest nitrate values and this relationship was clearer for birch than for pine. In addition, the experimental site in TR3 was immediately downstream of a braided section of the stream which appeared to experience greater substrate movements than the other sites on the Nethy. Flow related sediment accumulations appeared periodically in the TR3 leaf packs and may have resulted in changes in the availability and palatability of the leaf material to the macroinvertebrates. Herbst (1980) found that buried leaves lost weight more slowly than surface incubated leaves and were less likely to be consumed by macroinvertebrates.

It is now recognised that the diet of some shredders is not confined to conditioned leaf material. From a choice of 6 food items, Friberg and Jacobsen (1994) found that the overall food preference of two shredder species, the freshwater shrimp Gammarus pulex and the caddis Sericostoma personatum, was conditioned alder leaves followed by fresh filamentous green algae. Conditioned spruce needles were least preferred. Ledger and Hildrew (2000) also found that nemourid stoneflies, normally classified as shredders, were able to ingest large quantities of attached algae. However, while it is appreciated that the animals found in the packs in this study may have been feeding on a variety of food items, it is assumed that all those classified as shredders were capable of consuming leaf material.

Shredders, mainly plecopterans, or chironomids, some of which were potential shredders, were always the dominant macroinvertebrate groups found in the experimental leaf packs. This is to be expected as Egglishaw (1964) demonstrated that the distribution of shredders in a stream was correlated significantly with the distribution of plant detritus. Generally, the other non-shredder functional groups were not as well represented in the leaf packs when compared with the macroinvertebrates found in the open stream samples. The stream samples were collected to provide an indication of what animals were available to 
Table 3. Mean numbers of macroinverebrates collected by Hess sampling from the eight sites in the River Nethy during May 1996 (organisms $>10$ per Hess sample in bold). The animals most commonly found in the leaf packs throughout the study period are also indicated (\% composition in packs based on all samples $>20 \% * * *, 6-20 \% * *, 1-5 \% *$ ).

\begin{tabular}{|c|c|c|c|c|c|c|c|c|}
\hline Species & MS1 & $M S 2$ & $M S 3$ & MS4 & $T R 1$ & $T R 2$ & $T R 3$ & $T R 4$ \\
\hline NEMATODA & 10.4 & 3.8 & 2.4 & 1.2 & 1.0 & 3.8 & & 1.2 \\
\hline \multicolumn{9}{|l|}{ ANNELIDA } \\
\hline Oligochaeta & 0.2 & 1.4 & & 0.2 & 1.2 & 0.2 & & \\
\hline \multicolumn{9}{|l|}{ ARACHNIDA } \\
\hline Hydracarina & 0.4 & & 0.8 & 0.4 & 0.2 & 1.6 & & 1.6 \\
\hline \multicolumn{9}{|l|}{ EPHEMEROPTERA } \\
\hline Ameletus inopinatus Eaton & 2.8 & 0.6 & 0.2 & & 2.6 & 4.6 & 0.4 & \\
\hline Baetis rhodani (Pictet) $*$ & 66.8 & 20.2 & 9.0 & 1.8 & 42.4 & 4.8 & 5.2 & 3.8 \\
\hline Baetis muticus (L.) & 0.2 & 6.0 & 1.0 & 3.2 & & & 0.8 & 1.2 \\
\hline Rithrogena semicolorata (Curtis) & 1.6 & 29.2 & 3.6 & 10.8 & 6.6 & 1.2 & 5.6 & 2.2 \\
\hline Heptagenia lateralis (Curtis) & & 0.4 & 3.2 & 2.4 & 0.2 & 0.2 & & \\
\hline Ecdyonurus dispar (Curtis) & & & 1.4 & 2.4 & & 0.6 & 1.0 & 11.8 \\
\hline Caenis robusta Eaton & & & 0.8 & 2.6 & & 0.2 & & 0.4 \\
\hline \multicolumn{9}{|l|}{ PLECOPTERA } \\
\hline Rhabdiopteryx acuminata Klapalek & 3.6 & 0.6 & 0.2 & 0.4 & 2.4 & & & \\
\hline Brachyptera risi (Morton) & & & & & & & 0.6 & 0.6 \\
\hline \multicolumn{9}{|l|}{ Protonemura meyeri (Pictet) * } \\
\hline Protonemura montana Kimmins & 8.8 & & & & 3.2 & 0.4 & & 0.6 \\
\hline \multicolumn{9}{|l|}{ Protonemura praecox (Morton) $* *$} \\
\hline Amphinemura sulcicollis (Stephens) $* * *$ & 6.8 & 0.8 & 1.8 & 6.4 & 4.0 & 15.2 & 18.2 & 21.2 \\
\hline \multicolumn{9}{|l|}{ Leuctra hippopus (Kempny)* } \\
\hline Leuctra inermis Kempny ** & 111.6 & 17.8 & 10.1 & 21.0 & 72.2 & 47.4 & 52.4 & 21.6 \\
\hline Perlodes microcephala (Pictet) & 1.2 & & & & 0.8 & 0.6 & 0.4 & \\
\hline Diura bicaudata (L.) & & & & 1.0 & 0.2 & & & \\
\hline Isoperla grammatica $($ Poda $) *$ & 4.8 & 1.6 & 0.2 & 2 & 4.2 & 0.2 & 5.4 & 1.0 \\
\hline Chloroperla torrentium (Pictet) & 15.2 & 17.2 & 19.2 & 17.6 & 28.0 & 32.0 & 28.6 & 22.6 \\
\hline Chloroperla tripunctata (Scopoli) & 0.2 & 2.6 & 1.2 & 3.8 & & 0.2 & 2.2 & 8.4 \\
\hline \multicolumn{9}{|l|}{ COLEOPTERA } \\
\hline Dytiscidae spp. & 0.2 & & & 1.4 & & 6.8 & & \\
\hline Elmis aena (Muller) & 1.6 & 0.4 & 2.8 & 0.6 & 3.6 & 11.8 & & \\
\hline Limnius volckmari (Panzer) & 1.8 & 0.6 & 2.6 & 1.0 & & 7.4 & 1.4 & 1.2 \\
\hline \multicolumn{9}{|l|}{ TRICHOPTERA } \\
\hline \multicolumn{9}{|l|}{ Limnephilidae spp. * } \\
\hline Rhyacophila dorsalis (Curtis) & 1.0 & 0.6 & 0.2 & 0.2 & & 0.8 & 0.2 & 1.0 \\
\hline Glossosoma spp. & & 2.0 & 4.0 & 3.4 & & 0.8 & 0.4 & \\
\hline Polycentropus kingi (McLachlan) & & 0.6 & & 3.4 & 2.0 & 2.8 & & 0.2 \\
\hline Hydropsyche spp. & & & & & & & 0.2 & 3.6 \\
\hline \multicolumn{9}{|l|}{ DIPTERA } \\
\hline Dicranota spp. & 16.0 & 6.4 & 9.0 & 7.8 & 10.4 & 16.4 & 13.6 & 3.6 \\
\hline Chironomidae $* * *$ & 73.2 & 4.8 & 9.2 & 31.6 & 6.0 & 355.2 & 38.0 & 53.4 \\
\hline Simuliidae * & 1.0 & 7.4 & 8.4 & 2.2 & & 4.0 & 90.8 & 6.8 \\
\hline
\end{tabular}

colonise the leaf packs but as they were collected only once in May they might not faithfully capture important elements of macroinvertebrate dynamics. For example, as some of the invertebrates found in the Nethy emerge as adults in the spring, this might explain why three of the plecopteran species commonly found in the leaf packs during the early part of the experiment were not found in the stream samples in May.

In the latter stages of this experiment, chironomids generally became more abundant in the leaf packs and it is possible that many of these were collectors rather than shredders. It has been suggested that an increase in the 

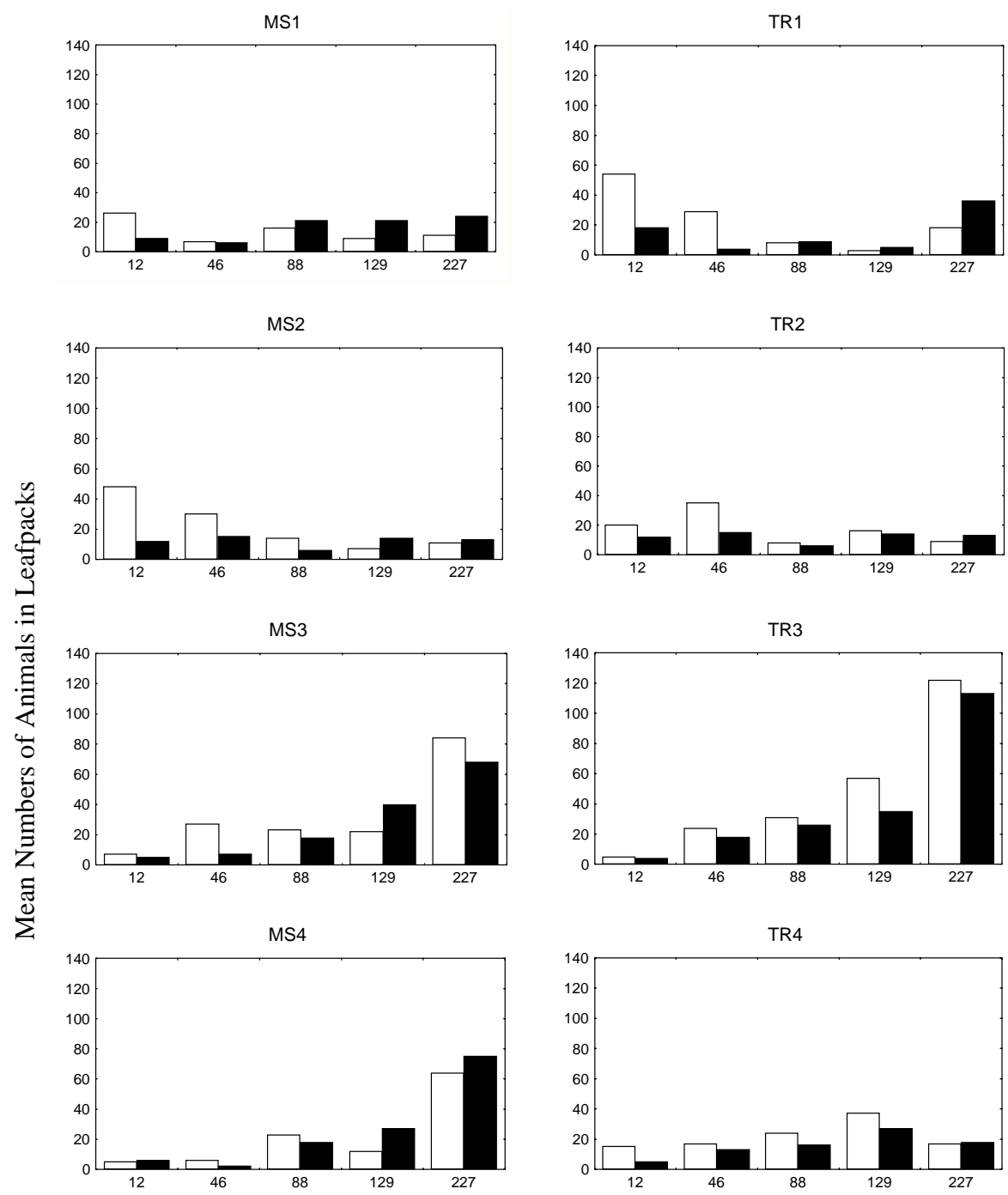

Days Processing

Birch $\square$ Pine

Fig. 4. Mean numbers of macroinvertebrates associated with experimental leaf pack at eight sites in the Nethy catchment from December 1995 to July 1996

collector functional feeding group in leaf packs could be related to an accumulation of fine particulate matter by the leaves (Richardson, 1992) or the production of faecal pellets by shredders in the leaf pack (Dobson et al., 1992).

Despite the close proximity of the birch and pine experimental packs, there were always more macroinvertebrates per unit weight of leaf material associated with the birch leaves. Shredders generally do not use leaf material as a food source until it has undergone a conditioning process which involves leaching of soluble organics and colonisation with stream microorganisms (Petersen and Cummins, 1974). The time taken to reach this conditioned stage can vary depending upon plant species, and normally takes longer for needles than leaves (Bärlocher et al., 1978). Consequently, as shredders continually move to feed on the best-colonised substrates (Cummins and Klug, 1979), it is not surprising that more macroinvertebrates, per unit weight of leaf material, were found with the birch leaves.

A delay in the macroinvertebrate colonisation of needles was reported for Pinus pinaster (Graca and Pereira, 1995) and Pinus radiata (O'Keefe and Lake, 1987). This delay is likely linked to the rate of colonisation and growth of aquatic hyphomycetes on pine needles. Bärlocher and Oertli (1978) demonstrated that extracts of Pinus leucodermus needles 
inhibited the growth of aquatic hyphomycetes while Bärlocher et al. (1978) found that conidiophores of these fungi developed slowly on Pinus resinosa needles.

It has been suggested that a mixed species riparian woodland will, due to differences in processing rates and time of leaf fall, provide a continuum of food resources for aquatic invertebrates (Cummins et al., 1989; Irons et al., 1988). Pine needles may have an important role in providing a long lasting food item. However, Bärlocher et al. (1978) suggested that, as it takes longer for needles to become colonised by aquatic micro-organisms, much of the coniferous detritus may be lost downstream before it is of any use to the stream community.

Leaf material is retained in streams by incorporation in the substrate, either in the upper open layers or buried, or by entrapment on other structural features such as tree roots, coarse woody debris and aquatic plants. Such retentive structural features are lacking in the river Nethy system and preliminary trial introductions of leaf material in two of the Nethy tributaries demonstrated that both needles and deciduous leaves can be washed downstream rapidly (Collen unpublished). These leaf release methods can provide accurate assessments of the retention properties of streams (Speaker et al., 1984). Hydrology and substrate related features are important factors affecting retention and riparian vegetation can be a major determinant of retentive properties of streams (Speaker et al., 1984). The retentive qualities of streams are an important factor influencing biological productivity and the introduction of features, particularly woody debris, to enhance litter retention has been recommended for stream restoration programmes (Laasonen et al., 1998; Laitung et al., 2002; Muotka and Laasonen, 2002)

The processing rate of pine needles was very slow at all sites in the river Nethy and limited evidence from two of the sites indicates that a significant amount of a needle may remain even after it has been in the stream for 500 days. Such lengthy processing periods may not necessarily adversely affect stream productivity if sufficient needles are retained within the stream. For example, Molles (1982) reported high shredder biomass in some North American coniferous streams and this was related to the large amount of detritus retained in these streams by abundant slowdecaying coniferous logs. However, in streams with poor retentive properties, the likelihood of needles remaining for the period required for successful processing will be small. This could have important implications for the productivity of streams where needles are the dominant allochthonous input.

Scots pine is the most widely distributed pine in the world (Skilling, 1990). In Scotland the expansion of Scots pinewoods is actively encouraged by grant schemes. Some of this expansion will be achieved by planting new pinewoods but the Scottish Forestry Grant Scheme encourages expansion through natural regeneration wherever possible. Regardless of the method used, the expansion of Scots pinewoods will result ultimately in more watercourses receiving pine needles as an integral component of their allochthonous energy input. Where pinewoods are developed in treeless areas, it may be many years before the riparian pine trees are large enough to provide retentive features in the form of woody debris.

The creation of pinewoods by planting will allow some control over the proportion of Scots pine trees in the riparian zone and provide scope for the inclusion of appropriate deciduous species. Relying on natural regeneration may, in some situations, result in watercourses where the riparian woodlands are dominated by Scots pine. Consequently, management plans for new and developing pinewoods should pay particular attention to the riparian woodland area. This study suggests that Scots pines should not be allowed to dominate riparian areas and that the establishment of suitable densities and species of deciduous trees should be encouraged. In addition, due to the relatively long processing time of pine needles, it might be desirable to enhance the retentive properties of some streams to maximise the time available for instream needle processing.

\section{Acknowledgements}

This work was jointly funded by the Scottish Executive Environment and Rural Affairs Department, Scottish Natural Heritage and the Royal Society for the Protection of Birds. The authors would like to thank the Nethy Reserve staff and colleagues in FRS for their help.

\section{References}

Anon., 2000. Forests for Scotland: The Scottish Forest Strategy. Forestry Commission, Edinburgh, UK. 92pp.

Bärlocher, F., 1985. The role of fungi in the nutrition of stream invertebrates. Bot. J. Linn. Soc., 91, 83-94.

Bärlocher, F. and Oertli, J.J., 1978. Inhibitors of aquatic hyphomycetes in dead conifer needles. Mycologia, 70, 964974.

Bärlocher, F., Kendrick, B. and Michaelides, J., 1978. Colonisation and conditioning of Pinus resinosa needles by aquatic hyphomycetes. Arch. Hydrobiol., 81, 462-474.

Beaumont, D., Duggan, D., Evans, G. and Taylor, S., 1995. Deer management and tree regeneration in the RSPB reserve at Abernethy forest. Scot. Forestry, 49, 155-161.

Benfield, E.F. and Webster, J.R., 1985. Shredder abundance and leaf breakdown in an Appalachian Mountain stream. Freshwater Biol., 15, 113-120.

Berg, B., Hannus, K., Popoff, T. and Theander, O., 1982. Changes in organic chemical components of needle litter during decomposition. Long-term decomposition in a Scots pine forest. I. Can. J. Bot., 60, 1310-1319. 
Collen, P., 1994. The influence of riparian tree selection on stream invertebrate production. Scot. Forestry, 48, 262-270.

Cowan, C.A., Oswood, M.W., Buttimore, C.A. and Flanagan, P.W., 1983. Processing and macroinvertebrate colonisation of detritus in an Alaskan subarctic stream. Hol.Ecol., 6, 340-348.

Cummins, K.W. and Klug, M.J., 1979. Feeding ecology of stream invertebrates. Ann. Rev. Ecol. Syst., 10, 147-172.

Cummins, K.W., Wilzbach, M.A., Gates, D.M., Perry, J.B. and Taliaferro, W.W., 1989. Shredders and riparian vegetation. Bioscience, 39, 24-30.

Dobson, M. and Cariss, H., 1999. Restoration of afforested upland streams - what are we trying to achieve? Aquat. Conserv.: Mar. Freshwater Ecosyst., 9, 133-139.

Dobson, M., Hildrew, A.G., Ibbotson, A. and Garthwaite, J., 1992. Enhancing litter retention in streams: do altered hydraulics and habitat area confound field experiments. Freshwater Biol., 28, 71-79.

Dobson, M., Hildrew, A.G., Orton, S. and Ormerod, S.J., 1995. Increasing litter retention in moorland streams: ecological and management aspects of a field experiment. Freshwater Biol., 33, 325-337.

Egglishaw, H.J., 1964. The distributional relationship between the bottom fauna and plant detritus in streams. J. Anim. Ecol., 33, 463-476.

Escudero, A., Sanz, S., Del Arco, J.M. and Garrido, M.V., 1991. Leaf litter decomposition in a mountain stream. Verh. Internat. Verein. Limnol., 24, 1987-1993.

Fisher, S.G. and Likens, G.E., 1972. Stream ecosystems: Organic energy budget. BioScience, 22, 33-35.

Friberg, N. and Jacobsen, D., 1994. Feeding plasticity of two detritivore-shredders. Freshwater Biol. 32, 133-142.

Gessner, M.O. and Chauvet, E., 1994. Importance of stream microfungi in controlling breakdown rates of leaf litter. Ecology, 75, 1807-1817.

Graça, M.A.S. and Pereira, A.P., 1995. The degradation of pine needles in a Mediterranean stream. Arch. Hydrobiol., 134, $119-128$.

Harriman, R., Bridcut, E.E. and Collen, P., 1998. The potential effects of natural regeneration of Caledonian pine on the ecology of the River Nethy and its tributaries. Scottish Natural Heritage Research, Survey and Monitoring Report, No.102, 97pp.

Herbst, G.N., 1980. Effects of burial on food value and consumption of leaf detritus by aquatic invertebrates in a lowland forest stream. Oikos, 35, 411-424.

Hess, A.D., 1941. New limnological sampling equipment. Limnol. Soc. Amer., Special Publication, 6, 1-5.

Irons, III J.G., Oswood, M.W. and Bryant, J.P., 1988. Consumption of leaf detritus by a stream shredder: Influence of tree species and nutrient status. Hydrobiologia, 160, 53-61.

Kaushik, N.K. and Hynes, H.B.N., 1971. The fate of dead leaves that fall into streams. Arch. Hydrobiol., 68, 465-515.

Laasonen, P., Muotka, T. and Kivijärvi, I., 1998. Recovery of macroinvertebrate communities from stream habitat restoration. Aquat. Conserv.: Mar. Freshwater Ecosyst., 8, 101-113.

Laitung, B., Pretty, J.L., Chauvet, E. and Dobson, M., 2002. Response of aquatic hyphomycete communities to enhanced stream retention in areas impacted by commercial forestry. Freshwater Biol., 47, 313-323.

Ledger, M.E. and Hildrew, A.G., 2000. Herbivory in an acid stream. Freshwater Biol.,43,545-556.
Merritt, R.W. and Cummins, K.W. (Eds.), 1984. An introduction to the aquatic insects of North America. 2nd edn. Kendall/Hunt Publishing Co. Dubuque, Iowa, USA.

Meyer, J.L. and Johnson, C., 1983. The influence of elevated nitrate concentration on rate of leaf decomposition in a stream. Freshwater Biol., 13, 177-183.

Molles, M.C., 1982. Trichopteran communities of streams associated with aspen and conifer forests: long-term structural change. Ecology, 63, 1-6.

Muotka, T. and Laasonen, P., 2002. Ecosystem recovery in restored headwater streams: the role of enhanced leaf retention. J. Appl. Ecol., 39, 145-156.

O'Keefe, M.A. and Lake, P.S., 1987. The decomposition of pine, eucalypt and acacia litter in a small upland Victorian stream. Bull. Aust. Soc. Limnol., 11, 15-32.

Ormerod, S.J., Rundle, S.D., Lloyd, E.C. and Douglas, A.A., 1993. The influence of riparian management on the habitat structure and macroinvertebrate communities of upland streams draining plantation forests. J. Appl. Ecol., 30, 13-24.

Petersen, R.C. and Cummins, K.W., 1974. Leaf processing in a woodland stream. Freshwater Biol., 4, 343-368.

Richardson, J.S., 1992. Food, microhabitat or both? Macroinvertebrate use of leaf accumulations in a montane stream. Freshwater Biol., 27, 169-176.

Robinson, C.T. and Gessner M.O., 2000. Nutrient addition accelerates leaf breakdown in an alpine springbrook. Oecologia, 122, 258-263.

Rosset, J., Bärclocher, F. and Oertli, J.J., 1982. Decomposition of conifer needles and deciduous leaves in two Black Forest and two Swiss Jura sreams. Int. Revue ges. Hydrobiol., 67, 695711.

Sedell, J.R., Triska, F. J. and Triska, N.S., 1975. The processing of conifer and hardwood leaves in two coniferous forest streams: I. Weight loss and associated invertebrates. Verh. Internat. Verein. Limnol., 19, 1617-1627.

Skilling, D.D., 1990. Pinus sylvestris L. Scots pine. In: Silvics of North America. Volume 1. Conifers, R.M. Burns and B.H. Honkala (Eds.), Agricultural Handbook 654. Washington, DC: US Department of Agriculture, Forest Services, USA. 489-496.

Speaker, R., Moore, K. and Gregory, S., 1984. Analysis of the process of retention of organic matter in stream ecosystems. Verh. Internat. Verein. Limnol., 22, 1835-1841.

Triska, F.J., Sedell, J.R. and Buckley, B., 1975. The processing of conifer and hardwood leaves in two coniferous forest stream: II. Biochemical and nutrient changes. Verh. Internat. Verein. Limnol., 19, 1628-1639.

Weatherly, N.S. and Ormerod, S.J., 1990. Forests and the temperature of upland streams in Wales: A modelling exploration of the biological effects. Freshwater Biol., 24, 109-122.

Webster, J.R. and Benfield, E.F., 1986. Vascular plant breakdown in freshwater ecosystems. Ann. Rev. Ecol. Syst., 17, 567-594.

Whiles, M.R. and Wallace, J.B., 1997. Leaf litter decomposition and macroinvertebrate communities in headwater streams draining pine and hardwood catchments. Hydrobiologia, 353, $107-119$

Zar, J.H., 1984. Biostatistical analysism. Prentice-Hall Inc., Englewood Cliffs, New Jersey, USA. 